\title{
Amifostine does not protect thyroid cancer cells in DNA damaging in vitro models
}

\author{
Joanna Klubo-Gwiezdzinska ${ }^{1,2}$, John Costello Jr3 ${ }^{3}$ Kirk Jensen³, Aneeta Patel ${ }^{3}$, \\ Rok Tkavc ${ }^{4}$, Douglas Van Nostrand ${ }^{2}$, Kenneth D Burman ${ }^{2}$, Leonard Wartofsky ${ }^{2}$ and \\ Vasyl Vasko ${ }^{3}$ \\ ${ }^{1}$ National Institute of Health, NIDDK, Office 10 Center Drive, Bethesda, Maryland, USA \\ ${ }^{2}$ Division of Endocrinology, Department of Medicine, Medstar Washington Hospital Center, Washington Hospital \\ Center, Northwest, Washington, District of Columbia, USA \\ ${ }^{3}$ Department of Pediatrics, Uniformed Services University of the Health Sciences, Bethesda, Maryland, USA \\ ${ }^{4}$ Department of Pathology, Uniformed Services University of the Health Sciences, Henry M. Jackson \\ Foundation for the Advancement of Military Medicine, Bethesda, Maryland, USA
}

Correspondence

should be addressed

to $\mathrm{V}$ Vasko

Email

vasyl.vasko.ctr@usuhs.edu

\begin{abstract}
Background: Amifostine is a potent scavenger of reactive oxygen species that is used for the salivary gland protection during therapy with radioactive iodine for thyroid cancer. There are no data on the potential effect of amifostine on thyroid cancer cells. Methods: We investigated the effects of the active form of amifostine (WR-1065) on the response of thyroid cancer cells to treatment with DNA-damaging agents. WR-1065 was examined in human thyroid cancer cell lines (FTC133, TPC1, BCPAP and C643) and embryonic fibroblast cells NIH3T3. DNA damage was induced by exposure to $\mathrm{H}_{2} \mathrm{O}_{2}$ $(0.1 \mathrm{mM})$, by treatment with the radiomimetic neocarzinostatin (NCS $250 \mathrm{ng} / \mathrm{mL}$ ) and by $\gamma$-radiation (6 Gy). DNA damage, cell viability and apoptosis were examined. Results: We demonstrated the selective action of WR-1065 (0.1 mM), which prevented oxidative stress-induced DNA damage in fibroblasts, but did not protect thyroid cancer cells from DNA damage and apoptosis documented by caspase-3 and PARP cleavage after exposure to $\mathrm{H}_{2} \mathrm{O}_{2}, \mathrm{NCS}$ and $\gamma$-radiation. Prolonged exposure to WR-1065 (0.1 mM for $24 \mathrm{~h}$ ) was toxic for thyroid cancer cells; this treatment decreased the number of viable cells by $8 \%$ in C643 cells, 47\% in TPC cells, 92\% in BCPAP cells and $82 \%$ in FTC 133 cells. The cytotoxic effects of WR-1065 were not associated with induction of apoptosis. Conclusions: Our data show that amifostine has no protective effect on thyroid cancer cells against DNA-damaging agents in vitro and suggest that amifostine will not attenuate the efficacy of radioiodine treatment in patients with thyroid cancer.
\end{abstract}

\section{Key Words \\ - thyroid cancer \\ - amifostine \\ - radiation \\ - DNA damage}

\section{Introduction}

Standard treatment of thyroid cancer consists of surgical resection and radioiodine $\left({ }^{131} \mathrm{I}\right)$ therapy (1). Depending on the risk stratification of the individual patient, the primary goal of the application of radioactive iodine (RAI) after surgery may be (1) remnant ablation; (2) adjuvant therapy (to decrease risk of recurrence and diseasespecific mortality, by destroying suspected but unproven metastatic disease) or (3) RAI therapy (to treat known persistent disease). In thyroid cancer cells, radiation causes irreparable damage to critical targets within the cell, such as DNA, RNA, proteins and lipids, leading to cell death. Nevertheless, subsequent to radiation, a number of defense mechanisms and processes are initiated in the damaged cells and tissues such as activation of DNA

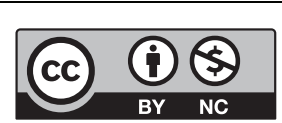

This work is licensed under a Creative Commons Attribution-NonCommercial 4.0 International License. 
repair, activation of signal transduction, expression of radiation response genes and stimulation of proliferation (2). These pathways can be important for cell or tissue recovery after radiation exposure but may also play a role in the development of toxicity.

Apart from specific uptake by thyroid tissue, the iodine 131 isotopes are accumulated actively in other tissues by an adenosine triphosphate (ATP)-dependent $\mathrm{Na}^{+} / \mathrm{K}^{+} / 2 \mathrm{Cl}^{-}$ transport. This causes an undesired accumulation of ${ }^{131} \mathrm{I}$ in breast tissue, parietal cells of the stomach and in acinar cells of salivary glands. Consequently, well-recognized side effects of high-dose radioiodine treatment are transient gastritis and sialadenitis and long-lasting xerostomia (3). The incidence of side effects related to salivary gland damage, such as painful salivary gland swelling, xerostomia, taste alterations and oral infections has been reported to be very variable, ranging from $2 \%$ to $67 \%$ of patients undergoing therapy with RAI (4). Therefore, reduction of side effects of high-dose RAI treatment emerged as a clinically important issue.

Amifostine (Ethyol, Alza Pharmaceuticals, Mountain View, CA, USA) is an inorganic thiophosphate cytoprotective agent known chemically as ethanethiol, 2-dihydrogen phosphate. It is a prodrug of a free thiol (WR-1065) that may act as a scavenger of free radicals generated in tissues exposed to cytotoxic drugs and binds to reactive metabolites of such drugs (5). Amifostine was developed originally as a radioprotective agent in a classified nuclear warfare project. Following declassification of the project, it was evaluated as a cytoprotective agent against toxicity of alkylating drugs and radiotherapy involving DNA-binding chemotherapeutic agents. Amifostine (WR2721) is a prodrug converted by alkaline phosphatase to its active, dephosphorylated form: WR1065. Differences in the alkaline phosphatase concentration of normal vs tumor tissues can result in greater conversion of amifostine in normal tissues (6). WR1065 can penetrate the cell membrane by both passive and active diffusion mechanisms. Inside the cell, WR-1065 provides an alternative target to DNA and RNA for the reactive molecules of alkylating or platinum-based agents and acts as a potent scavenger of the oxygen free radicals induced by ionizing radiation and some chemotherapy agents.

In vitro data demonstrated that WR1065 efficiently reduces the extent of DNA damage caused by free radicals (7). In addition, protective effects of amifostine have been attributed to activation of DNA repair signaling and activation of anti-apoptotic signaling pathways. In vivo studies have shown that amifostine is accumulated more rapidly in various normal tissues than in tumors.
The selective protection of non-malignant tissues is believed to be due to higher alkaline phosphatase activity, higher $\mathrm{pH}$, and vascular microcirculation of normal tissues. These observations have led to the concept that amifostine could be used clinically to limit the side effects of radiotherapy and chemotherapy on normal tissues, while not affecting its therapeutic efficacy on tumors (8). The drug is now used clinically to reduce the cumulative renal toxicity associated with administration of platinum drugs in patients treated for ovarian cancers and radiationinduced salivary gland damage in patients with head and neck and lung cancers.

The effects of amifostine on salivary gland function also were examined in patients receiving high-dose RAI therapy $(3,9)$. It has been reported that parenchymal damage in salivary glands induced by high-dose radioiodine treatment can be significantly reduced by amifostine in patients with thyroid cancer. More recent data, however, suggested a lack of salivary gland protection after therapy with amifostine in patients with thyroid cancer treated with radioiodine (10). These conflicting data from studies in different institutions could be related to the different patient populations, as well as to the different regimens of treatment with amifostine. Without clarity of potential efficacy, the American Thyroid Association guidelines for thyroid nodules and thyroid cancer currently state that the evidence is insufficient to recommend for or against amifostine usage for salivary gland protection in patients undergoing therapy with RAI.

Interestingly, several experimental and pre-clinical models suggest that amifostine may also act through more specific mechanisms than broad-range, free radical scavenging and may have different effects in normal vs cancer cells. In nude mice carrying xenografts of human ovarian cancer cells, amifostine has been reported to potentiate tumor growth inhibition by a standard dose of platinum drugs (11). Moreover, WR1065 has been shown to delay cell-cycle progression in cultured cancer cells (12), to affect the phosphorylation of topoisomerase IIa, and to affect the expression of genes associated with cell proliferation such as c-myc and thymidine kinase (13). It has also been reported that exposure of cultured cells to WR1065, as well as to the prodrug WR2721, induced accumulation and activation of p53, and that this effect correlates with induction of p53 target genes (e.g. CDK inhibitor p21, pro-apoptotic genes bax-1, killer/DR5, and CD95/APO-1/fas) and several genes involved in the control of intracellular redox metabolism (14). Together these data raise the possibility that, in addition to its radioprotective activity in normal cells, amifostine may 
enhance radiation-inducible apoptosis in cancer cells harboring oncogene mutations.

It has to be noted that, despite the clinical use of amifostine in treatment of thyroid cancer patients, there is no information on its molecular mechanisms of action in thyroid cancer cells. We investigated the effects of the active form of amifostine (WR-1065) on the response of thyroid cancer cells to treatment with DNA-damaging agents and assessed its effects on thyroid cancer cell growth, differentiation and apoptosis.

\section{Materials and methods}

\section{Cell lines and culture conditions}

The protocol for study was approved by the Institutional Review Board at the Washington Hospital Center and Uniformed Services University of the Health Sciences. Human thyroid cancer cell lines derived from follicular thyroid cancer (FTC133), papillary thyroid cancer (TPC1 and BCPAP) and anaplastic thyroid cancer (C643) cells, as well as NIH3T3 mouse embryonic fibroblast cells were obtained from Dr Motoyasu Saji (The Ohio State University), with permission from the researchers who originally established the cell lines. All thyroid cancer cell lines had been tested and authenticated by DNA analysis to be of thyroid origin. The short tandem repeat (STR) profiling was performed at the Ohio State University before the start of experiments. These cell lines express common thyroid oncogenes including BRAF V600E (BCPAP and C643), RET/PTC1 (TPC1), loss of PTEN expression (FTC133), Asp259Tyr TP53 mutation (BCPAP), Arg248Gln TP53 mutation (C643) and HRAS mutation (C643 cells).

Cancer cells were propagated in RPMI-1640 medium (Invitrogen, ThermoFisher Scientific) supplemented with $5 \%$ fetal bovine serum. All experiments were performed using thyroid cancer cell lines that had been passaged fewer than 15 times. STR has been performed again at the conclusion of the experiments and re-authenticated the cell lines - 100\% BCPAP, 100\% C643, 100\% TPC and $>80 \%$ FTC133. For experiments with pharmacological agents, thyroid cancer cells were incubated with either control medium or medium containing the active, dephosphorylated form of amifostine, WR-1065 (SigmaAldrich). The radiomimetic drug neocarzinostatin (NCS; Sigma-Aldrich) was added to fresh cell media with a final concentration of $250 \mathrm{ng} / \mathrm{mL}$.

\section{Cell viability and proliferation assays}

Cell viability was determined by alamarBlue assay (Invitrogen, ThermoFisher Scientific) according to manufacturer instructions. Cells were plated in 96-well cell culture plates and grown until 50\% confluence was reached. Cells were treated with WR-1065 at concentrations varying from $0.1 \mathrm{mM}$ to $1 \mathrm{mM}$ for $24 \mathrm{~h}$. Alamar blue solution was added to each well, and cells were incubated for $4 \mathrm{~h}$. The absorbance of Alamar blue reagent was monitored at $570 \mathrm{nM}$ and $600 \mathrm{nM}$ by spectrophotometer.

Cell death also was assessed by propidium iodide (PI) staining (Life Technologies).

For the cell proliferation assay, thyroid cancer cells were plated at a density of 50,000 cells/well in 6-well plates. Cells adhered overnight and then were treated with WR-1065 at concentrations varying from $0.1 \mathrm{mM}$ to $1 \mathrm{mM}$. After incubation for $24 \mathrm{~h}$, cell proliferation rate was determined by cell counting using Vi-CELL Cell Viability Analyzer from Beckman Coulter (Fullerton, CA, USA).

\section{Protein extraction and Western blot analysis}

Thyroid cancer cells were incubated with ice-cold cell lysis buffer, scraped, centrifuged and the supernatant was stored at $-80^{\circ} \mathrm{C}$. Twenty-five micrograms of total protein lysate were suspended in reduced SDS sample buffer and protein lysates were subjected to SDS-PAGE (7\%). The separated proteins were transferred to nitrocellulose membranes (0.2- $\mu \mathrm{m}$ pore size; Invitrogen) by electrophoretic blotting (Invitrogen). Non-specific binding was prevented by blocking with $0.1 \%$ Tween 20 in PBS (PBS-T) containing $5 \%$ nonfat dry milk overnight at $4^{\circ} \mathrm{C}$.

Membranes were incubated overnight with the primary antibody against $\gamma \mathrm{H} 2 \mathrm{AX}$, PARP, caspase- 3 and $\beta$-actin (Cell Signaling Technology). Membranes were then incubated with secondary antibody in PBS-T containing 5\% nonfat dry milk for $1 \mathrm{~h}$ at room temperature. After washing with PBS-T four times (15 min/wash), protein bands on the blots were visualized using the Li-COR Odyssey imaging system (LI-COR Biosciences Lincoln, NE, USA).

\section{In vitro irradiation}

Exponentially growing thyroid cancer cells were plated $24 \mathrm{~h}$ before irradiation in 6-well plates in 10\% FBS-containing RPMI medium. Immediately before irradiation, cell culture medium was replaced by fresh culture medium, and cells

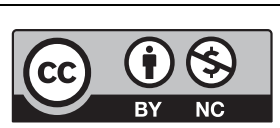

This work is licensed under a Creative Commons Attribution-NonCommercial 4.0 International License. 
were exposed to $\gamma$-irradiation (6 Gy; ${ }^{60} \mathrm{Co}$, GammaCell 40; $35 \mathrm{~Gy} / \mathrm{h})$. At $24 \mathrm{~h}$ post irradiation, thyroid cancer cells were collected for protein extraction.

\section{Comet assay}

DNA damage was determined by Comet assay. This assay is based on the separation from supercoiled DNA of DNA loops containing strand breaks (SSBs and DSBs) that become free to migrate out of the nucleus toward the anode during an alkaline electrophoresis in a solution of $0.3 \mathrm{M} \mathrm{NaOH}, 1 \mathrm{mM}$ EDTA and $\mathrm{pH}>13$. DNA images were captured after staining with ethidium bromide $(20 \mu \mathrm{g} / \mathrm{mL})$ with a Nikon imaging microscope with a $40 \times$ objective lens. For quantification, the comets were classified into different categories. We measured the comet score in 200 randomly selected cells per slide. Results were expressed as the percentage of each stage of comets per slide.

\section{Results}

WR-1065 did not protect thyroid cancer cells against DNA damage in an oxidative stress model

To test the hypothesis that amifostine, a radioprotective compound with antioxidant properties, may attenuate DNA damage in thyroid cancer cells, we examined the effects of WR-1065 (the active thiol form of amifostine) in FTC, PTC and ATC-derived cell lines. To induce DNA damage in thyroid cancer cells, we used an oxidative stress model and performed treatment with $\mathrm{H}_{2} \mathrm{O}_{2}$ $(0.1 \mathrm{mM})$. As a control, we also examined the effects of WR-1065 (0.1 mM) on $\mathrm{H}_{2} \mathrm{O}_{2}$-inducible DNA damage in NIH3T3 fibroblasts.

DNA damage in thyroid cancer cells (FTC133, TPC1, BCPCP and C643) and in NIH3T3 fibroblasts was quantified by Comet assay 60 min after exposure to $\mathrm{H}_{2} \mathrm{O}_{2}$. As demonstrated in Fig. 1A, an increase in the length and

A FTC133 TPC1 BCPAP $\mathrm{C643}$ NIH3T3

Control

$\mathrm{H} 2 \mathrm{O} 2(0.1 \mathrm{mM})$
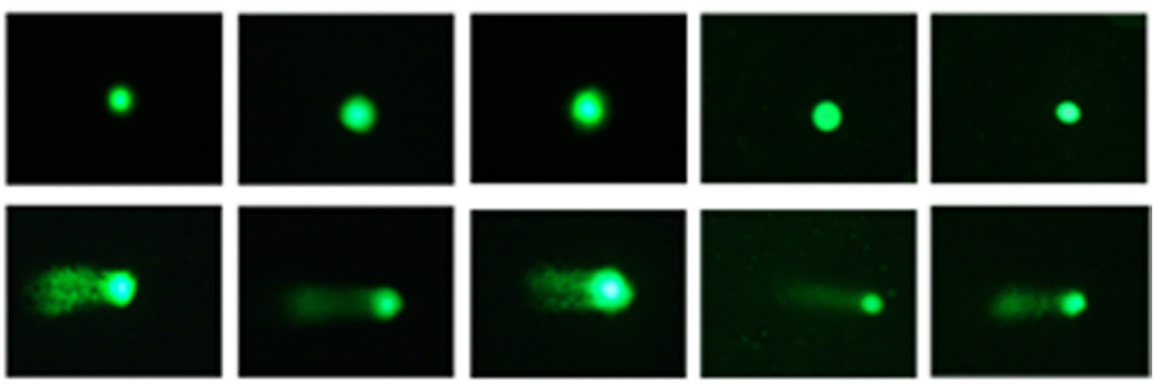

$\mathrm{H} 2 \mathrm{O} 2 \mathrm{\&}$

WR-1065
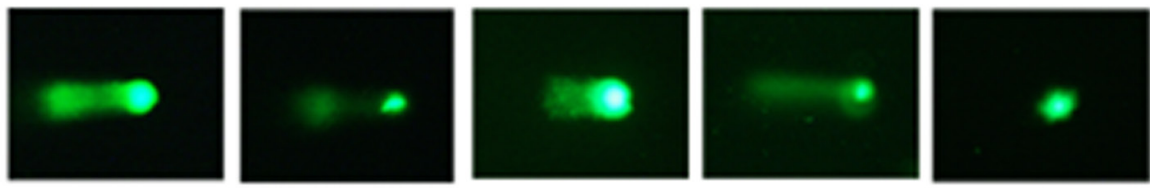

B

\section{FTC133}

\section{NIH3T3}

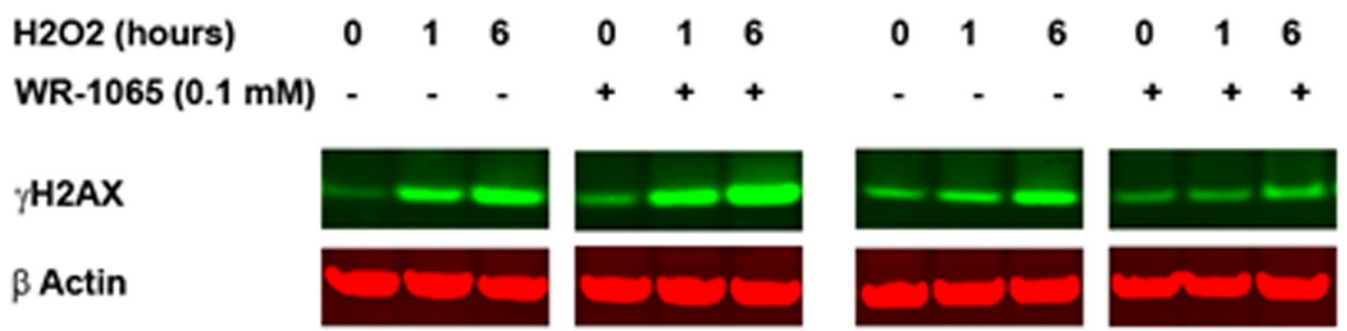

Figure 1

(A) Increase in the length and intensity of the comet tail evolving in parallel with a decrease in the nuclear DNA content, indicating DNA damage was observed in thyroid cancer cells as well as in NIH3T3 cells exposed to the $\mathrm{H}_{2} \mathrm{O}_{2}(0.1 \mathrm{mM}$ for $1 \mathrm{~h})$. Pre-treatment with WR-1065 (0.1 mM for $1 \mathrm{~h}$ ) did not prevent $\mathrm{H}_{2} \mathrm{O}_{2}$-induced DNA damage in examined thyroid cancer cell lines, but significantly attenuated $\mathrm{H}_{2} \mathrm{O}_{2}$-inducible DNA damage in NIH3T3 cells. (B) Treatment with $\mathrm{H}_{2} \mathrm{O}_{2}(0.1 \mathrm{mM})$ was associated with increased phosphorylation of histone $\mathrm{H} 2 \mathrm{AX}$ in FTC 133 cells. Pre-treatment with WR-1065 (0.1 mM) did not prevent $\mathrm{H}_{2} \mathrm{O}_{2}$-inducible activation of DNA damage repair signaling in FTC-133 cells, but attenuated expression of $\gamma \mathrm{H} 2 \mathrm{AX}$ in NIH3T3 cells.

$\begin{array}{lr}\text { http://www.endocrineconnections.org } & \text { ○ } 2017 \text { The authors } \\ \text { DOI: } 10.1530 / \text { EC-17-0138 } & \text { Published by Bioscientifica Ltd }\end{array}$

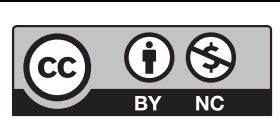

This work is licensed under a Creative Commons Attribution-NonCommercial 4.0 International License. 
intensity of the comet tail evolving in parallel with a decrease in the nuclear DNA content, indicating DNA damage, was observed in thyroid cancer cells as well as in NIH3T3 fibroblast cells exposed to the $\mathrm{H}_{2} \mathrm{O}_{2}(0.1 \mathrm{mM}$ for $1 \mathrm{~h})$. Pretreatment with WR-1065 (0.1 mM for $1 \mathrm{~h})$ did not prevent $\mathrm{H}_{2} \mathrm{O}_{2}$-induced DNA damage in examined thyroid cancer cell lines. Consistent with previously reported data; however, pre-treatment with WR-1065 significantly attenuated $\mathrm{H}_{2} \mathrm{O}_{2}$ inducible DNA damage in NIH3T3 fibroblast cells.

We also examined the activation of DNA repair signaling by detection of the $\gamma$ - $\mathrm{H} 2 \mathrm{AX}$ after $\mathrm{H}_{2} \mathrm{O}_{2}$ treatments. As demonstrated in Fig. $1 \mathrm{~B}$, treatment with $\mathrm{H}_{2} \mathrm{O}_{2}(0.1 \mathrm{mM})$ was associated with a time-dependent increase in the phosphorylation of histone H2AX in thyroid cancer cells. Pre-treatment with WR-1065 (0.1 mM) did not prevent $\mathrm{H}_{2} \mathrm{O}_{2}$-inducible activation of DNA damage repair signaling in FTC-133 cells (Fig. 1B) as well as in other examined thyroid cancer cell lines (data not shown). In NIH3T3 fibroblast cells, pre-treatment with WR-1065 did attenuate the $\mathrm{H}_{2} \mathrm{O}_{2}$-inducible expression of $\gamma$-H2AX.
Together these data demonstrated that WR-1065 prevented oxidative stress-inducible DNA damage in NIH3T3 fibroblast cells, but did not attenuate DNA damage in thyroid cancer cells exposed to oxidative stress.

WR-1065 did not protect thyroid cancer cells against DNA damage that was induced by the radiomimetic neocarzinostatin (NCS) or $\gamma$-radiation

As $\mathrm{H}_{2} \mathrm{O}_{2}$ is rapidly degraded when added to the cells, we used a pharmacological radiomimetic neocarzinostatin (NCS) to determine the effects of WR-1065 on thyroid cancer cells subjected to the chronic exposure to the DNA-damaging agent. Treatment with NCS (250 nM for $24 \mathrm{~h}$ ) was associated with DNA damage and phosphorylation of histone H2AX (Fig. 2A) in all examined thyroid cancer cell lines. Treatment with NCS also was associated with caspase-3 cleavage, indicating induction of apoptosis. Treatment with WR-1065 $(0.1 \mathrm{mM})$ did not prevent NCS-inducible DNA damage and apoptosis in any of thyroid cancer cells examined.
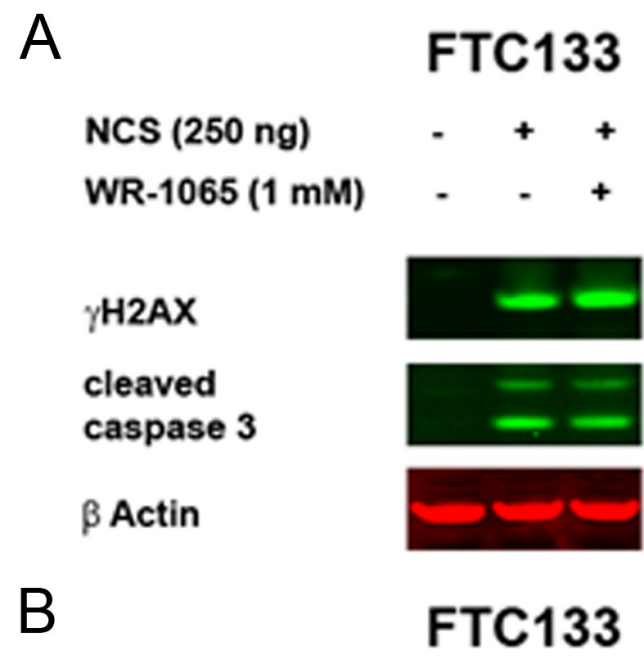

radiation
WR-1065 $(1 \mathrm{mM})$

$\gamma \mathrm{H} 2 \mathrm{AX}$

cleaved

caspase 3

$\beta$ Actin
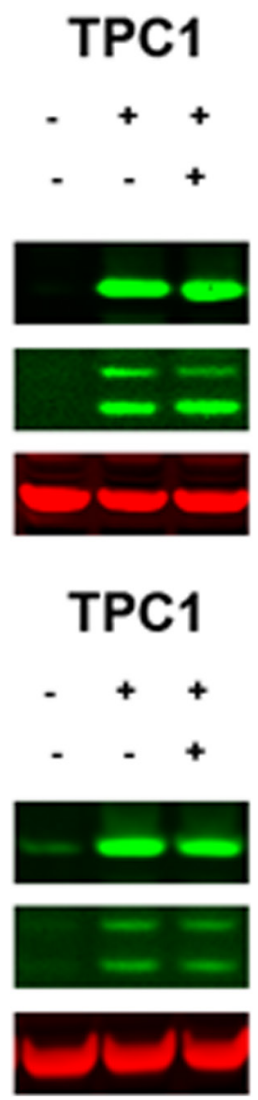
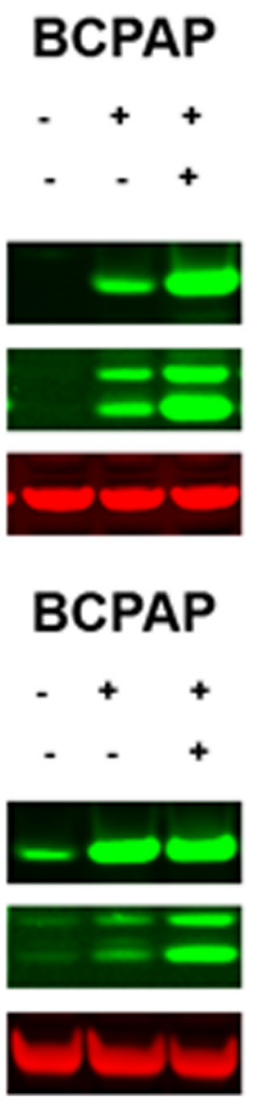

C643

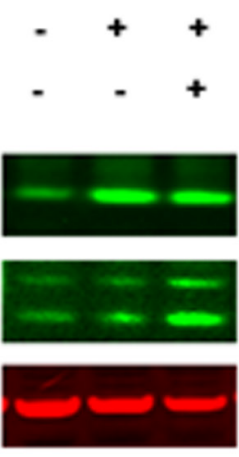

C643

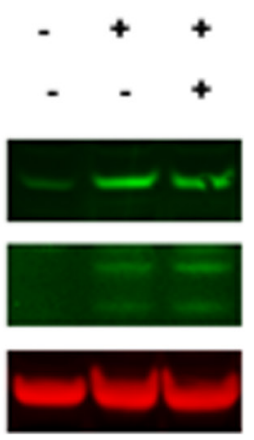

Figure 2

(A) Treatment with NCS (250 nM for 24h) was associated with DNA damage and phosphorylation of H2AX, as well as caspase-3 cleavage. WR-1065 did not prevent expression of $\gamma \mathrm{H} 2 \mathrm{AX}$ or caspase-3 cleavage. (B) Western blot with anti- $\gamma \mathrm{H} 2 \mathrm{AX}$ and anti-caspase-3 shows no protective effects of WR-1065 on the $\gamma$-radiation-induced DNA damage and apoptosis in thyroid cancer cells.

$\begin{array}{lr}\text { http://www.endocrineconnections.org } & \text { ○ } 2017 \text { The authors } \\ \text { DOI: } 10.1530 / \text { EC-17-0138 } & \text { Published by Bioscientifica Ltd }\end{array}$

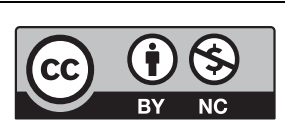

This work is licensed under a Creative Commons Attribution-NonCommercial 4.0 International License. 
After establishing that WR-1065 had limited effects in our NCS-induced DNA damage model, we next examined the effects of WR-1065 on thyroid cancer cells exposed to $\gamma$-radiation. As demonstrated in Fig. 2B, $\gamma$-radiation (6 Gy) induced expression of $\gamma$-H2AX in all examined cell lines, with the most significant effects in PTC-derived TPC- 1 and BCPAP cells. Induction of caspase- 3 cleavage after irradiation was noted only in TPC-1 and BCPAP cells. Concurrent treatment with WR-1065 had no inhibitory effects on expression of $\gamma-\mathrm{H} 2 \mathrm{AX}$ and did not prevent apoptosis in thyroid cancer cells that were exposed to $\gamma$-radiation. Moreover, in BCPAP cells, treatment with WR-1065 was associated with more prominent DNA damage after treatment with NCS and $\gamma$-radiation.

Together these data showed that WR-1065 did not protect thyroid cancer cells against DNA damage or apoptosis and suggested that WR-1065 itself could be toxic for thyroid cancer cells.

\section{Chronic exposure to WR-1065 induces thyroid cancer cell death}

Treatment with escalating doses of WR-1065 (ranging from 0 to $1 \mathrm{mM}$ ) was associated with a progressive decrease in the number of viable cells in all examined thyroid cancer cell lines. Vi-Cell analysis showed that PTC-derived cells (TPC1 and BCPAP) and FTC-derived cells (FTC-133) were more sensitive to the cytotoxic effects of WR-1065 than the ATC-derived C643 cell line (Fig. 3A). In C643, TPC1, BCPAP and FTC-133 cells, the number of viable cells was decreased by $8,47,92$, and $82 \%$, respectively, after exposure to WR-1065 at a concentration $0.1 \mathrm{mM}$ for $24 \mathrm{~h}$.

Treatment with WR-1065 was associated with morphological changes including cell swelling and cell detachment from the plate (Fig. 3B). Nuclear accumulation of PI, indicating cell death, was detected in TPC, BCPAP and FTC-133 cells, but not in C643 cells, after treatment with WR-1065 $0.1 \mathrm{mM}$ (Fig. 3B) and in all examined thyroid cancer cells after treatment with WR-1065 $0.25 \mathrm{mM}$

To determine if apoptotic signaling is involved in the response to treatment with WR-1065, we performed Western blot analysis with anti-caspase-3 and anti-PARP using protein extracts from thyroid cancer cells exposed to WR-1065, at a concentration of $0.1 \mathrm{mM}$ for $24 \mathrm{~h}$. As demonstrated in Fig. 3C, treatment with WR-1065 was not associated with cleavage of caspase- 3 or PARP in examined thyroid cancer cell lines.

Together, these data showed that WR-1065 is toxic for thyroid cancer cells and suggested that caspase-independent mechanisms contribute to WR-1065inducible thyroid cancer cell death.

\section{Discussion}

Amifostine has long been recognized as a potential radioprotective agent (15). Randomized trials have shown that this drug reduces the severity and duration of xerostomia in patients receiving daily radiotherapy for head and neck cancer. Amifostine also reduces cisplatininduced nephrotoxicity in patients with ovarian cancer (16). The drug has been approved for these two clinical indications by European and US regulatory agencies.

Treatment with RAI in patients with thyroid cancer can be associated with damage to the salivary gland parenchyma, resulting in salivary gland swelling and pain, sialadenitis, xerostomia, taste alterations, infection, stomatitis, candidiasis and herpetic infection that significantly affects the quality of life. Protection of salivary gland function has been the focus of research in patients with thyroid cancer, and in some, but not all studies, amifostine has been shown to decrease radiationinduced damage of salivary glands in patients with thyroid cancer $(3,9)$. Pre-clinical in vivo models also document amifostine-induced protection of the salivary glands from the RAI-related damage (17).

Despite these encouraging results, concerns about tumorprotective activity of amifostine have led to controversy regarding the appropriate setting for its use. Pre-clinical experiments with tumor-bearing animals demonstrated that normal tissues as well as cancer cells have varying degrees of protection, depending on the drug scheduling, dose of radiation and tissue characteristics (18). It also has been shown that oncogene mutations can modulate the effects of amifostine on cancer cell response to radiation (19).

In this study, we examined the effects of the active form of amifostine (WR-1065) on the thyroid cancer cell response to treatment with DNA-damaging agents. For induction of DNA damage, we used three models: oxidative stress (treatment with $\mathrm{H}_{2} \mathrm{O}_{2}$ ), treatment with the radiomimetic neocarzinostatin (NSC) and $\gamma$-radiation. These DNA-damaging treatments lead to the activation of DNA damage repair signaling and overexpression of $\gamma$-H2AX in thyroid cells derived from follicular cancer (FTC133), papillary cancer (TPC1 and BCPAP), anaplastic cancer (C643) as well as in normal fibroblasts (NIH3T3 cells). Pre-treatment with WR-1065 was not protective for any thyroid cancer cell lines but significantly decreased the extent of DNA damage in fibroblasts.

This work is licensed under a Creative Commons Attribution-NonCommercial 4.0 International License. 
A

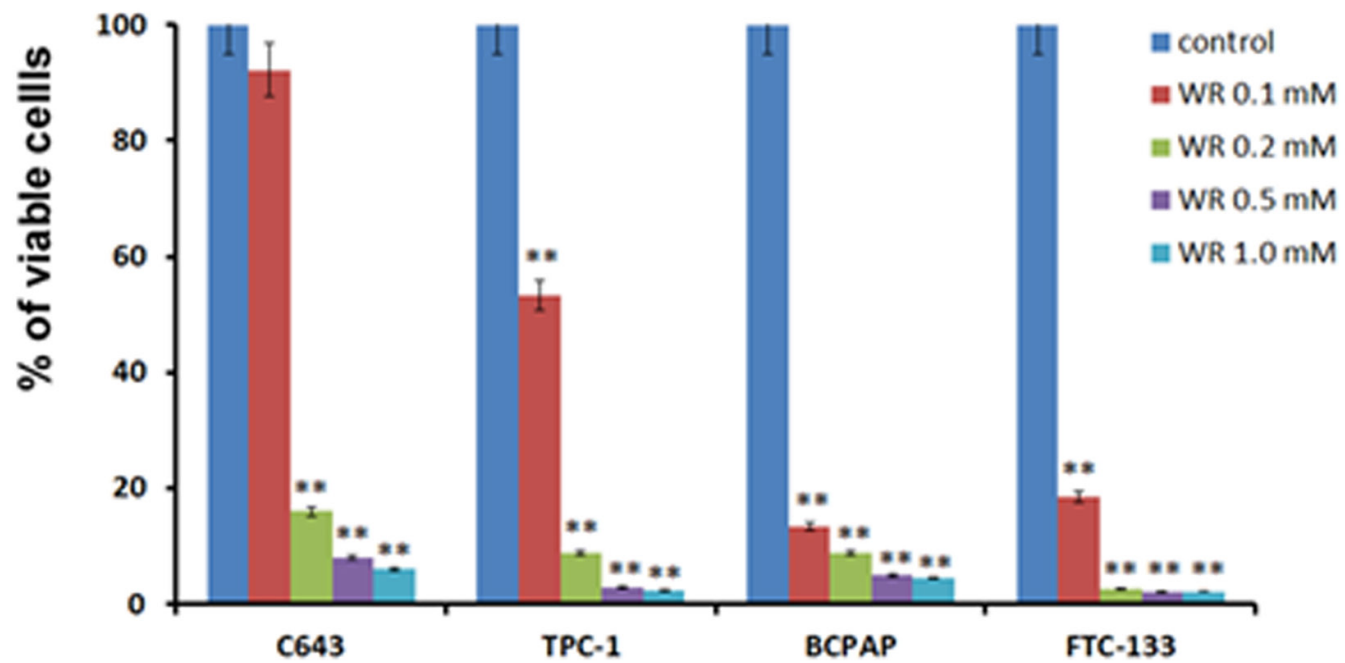

B

Control

WR-1065

(0.1 mM)

C643

TPC1
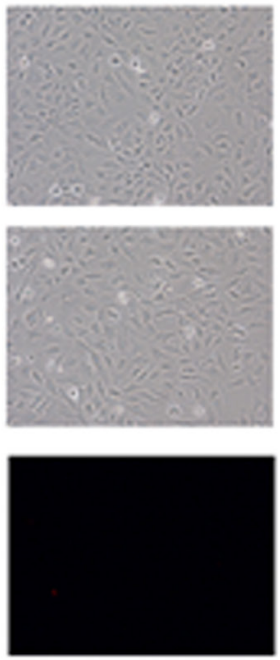

C

\section{total PARP cleaved PARP \\ cleaved caspase 3 \\ $\beta$ Actin}
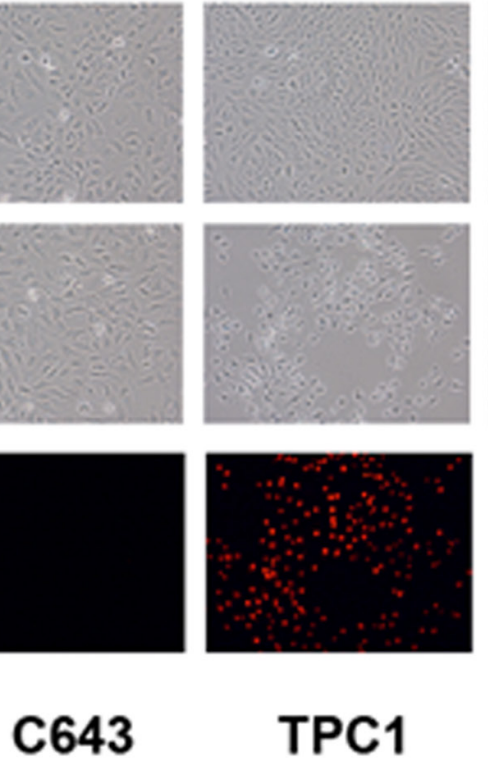

TPC1
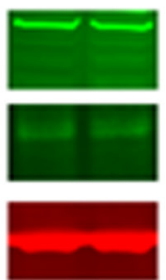

BCPAP

BCPAP
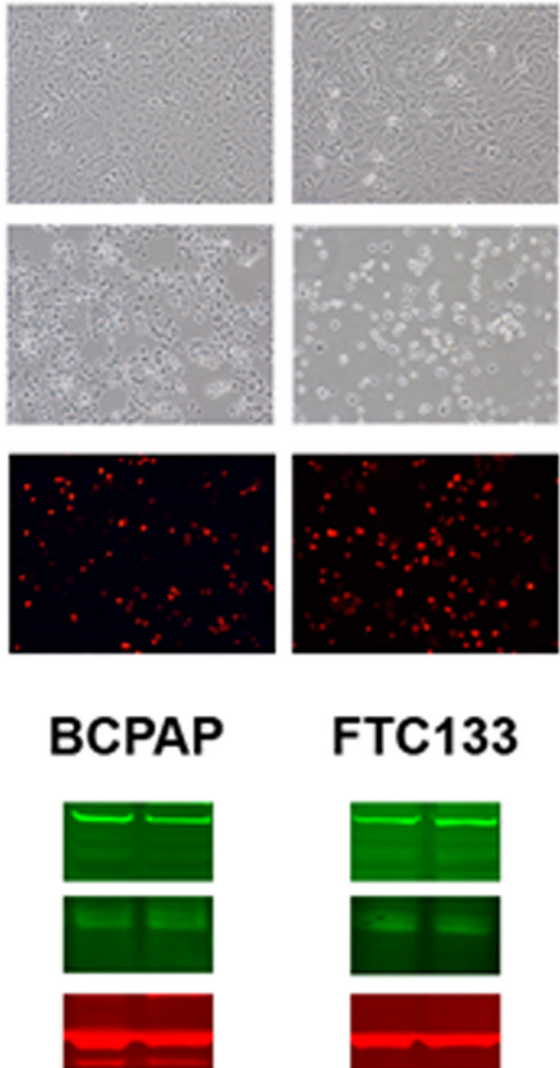

FTC133

FTC133
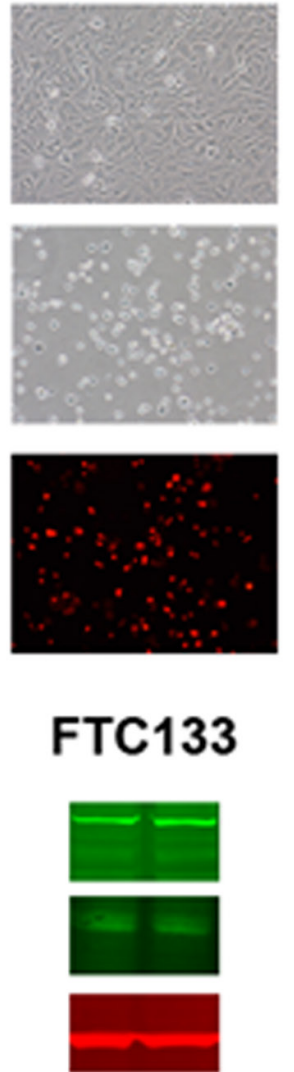

Figure 3

(A) In C643, TPC, BCPAP and FTC-133 cells, the number of viable cells was decreased by 8, 47, 92 and 82\%, respectively, after exposure to WR-1065 at a concentration of $0.1 \mathrm{mM}$ for $24 \mathrm{~h}$. (B) Nuclear accumulation of PI, indicating cell death, was detected in TPC, BCPAP and FTC-133 cells, but not in C643 cells after treatment with WR-1065 at a concentrations $0.1 \mathrm{mM}$. (C) Treatment with WR-1065 was not associated with cleavage of caspase-3 or PARP in examined thyroid cancer cell lines.

$\begin{array}{lr}\text { http://www.endocrineconnections.org } & \text { ○ } 2017 \text { The authors } \\ \text { DOI: } 10.1530 / \text { EC-17-0138 } & \text { Published by Bioscientifica Ltd }\end{array}$

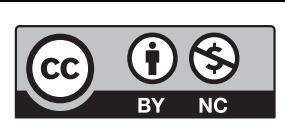

This work is licensed under a Creative Commons Attribution-NonCommercial 4.0 International License. 
The molecular mechanisms of selective protection of normal cells but not thyroid cancer cells are not clear. It is believed that amifostine is selectively activated by normal cells, and this process is thought to be facilitated by differences in the concentrations of alkaline phosphatases between normal and cancer cells. In our experiments, however, we used an active form of amifostine, WR1065, not requiring conversion by alkaline phosphatases. This observation suggests that differences in the intracellular targets for amifostine, rather than differences in the expression of enzymes catalyzing its conversion to an active form, could account for the differential response of normal and cancer cells.

It has been shown that amifostine is a potent activator of p53 in cell lines expressing wild-type p53. It was suggested that activation of p53 may be the factor responsible for differential response to amifostine between normal and cancer cells in vivo (20). Luo and coworkers documented that sensitivity of endometrial cancer cells to the therapeutic effect of paclitaxel in combination with amifostine was dependent upon the status of p53. A tumor with a nonsense TP53 mutation showed increased therapeutic response to paclitaxel and amifostine as measured by tumor weight compared to a tumor with wild-type TP53 (21). Interestingly, Pataer and coworkers showed that amifostine alone can induce apoptosis of human lung cancer cells and that the combination of an adenoviral vector bearing p53 with amifostine resulted in significantly higher levels of apoptosis (19). To determine whether oncogene mutations contribute to the thyroid cancer cellular response to amifostine, we examined thyroid cancer cell lines harboring different p53 mutations: BCPAP with Asp259Tyr TP53 mutation and C643 with Arg248GlnTP53 mutation, and cells with wild-type TP53: FTC133 and TPC cells. Moreover, the examined cell lines were characterized by BRAF V600E mutation (BCPAP), RET/PTC1 translocation (TPC1 cells) and HRAS mutation (C643 cells). Our results showed that amifostine was not protective for thyroid cancer cells irrespective of their mutation status.

Since amifostine acts as a scavenger of reactive oxygen species to reduce DNA damage, we examined the effects of amifostine on the activation of DNA damage/ repair signaling in thyroid cancer cells in an oxidative stress model. It is known that oxidative stress causes DNA damage and the generation of reactive oxygen species (ROS), with subsequent rapid activation of wild-type p53, ataxia telangiectasia mutated (ATM), and ATM and Rad3-related proteins as well as the phosphorylation of H2AX (22). By examining phospho-H2AX in response to the treatment with $\mathrm{H}_{2} \mathrm{O}_{2}$, we showed that amifostine did not prevent the activation of DNA repair signaling in thyroid cancer cells.

The mainstay of therapy for high-risk patients with thyroid cancer is treatment with radioiodine. Our data showed that an active form of amifostine, WR1065, has no protective effect on thyroid cancer cells against DNAdamaging agents in vitro and suggests that amifostine will not attenuate the efficacy of radioiodine treatment in patients with thyroid cancer.

Recent studies provided evidence that amifostine has a role as an antitumor agent. Amifostine has been evaluated as a possible treatment for myelodysplastic syndrome because of its stimulation of bone marrow hematopoiesis. Additional work documented that amifostine can exert a direct effect on myelodysplastic syndrome cells through both inhibition of growth and apoptosis and that this effect appears to be independent of p53 status (23). Brenner and coworkers documented synergistic effects of amifostine and radiation in induction of apoptosis of myoblast cells (24). Dai and coworkers revealed dual-specificity of amifostine action: anticancer synergy between amifostine and paclitaxel in vitro and in vivo in endometrial cancer models, whereas amifostine maintained a protective role in peripheral blood profiles (25). To determine the possible antitumor activity of amifostine in thyroid cancer, we examined the effects of WR1065 on growth of thyroid cancer cells in vitro. Our results demonstrated that WR1065 was toxic for thyroid cancer cells, especially for cells harboring a BRAF mutation. The possible sensitivity of tumors with BRAF mutation to amifostine was suggested by reports of amifostine use in patients with melanoma. A clinical trial in patients with metastatic melanoma showed that treatment with amifostine in combination with cisplatin every 3-4 weeks produced response rates of 50\%, well above the response rates of less than $20 \%$ typically seen with cisplatin alone (26).

Molecular mechanisms underlying response to amifostine in BRAF-positive cells need to be elucidated, and further experiments examining the effects of amifostine on BRAF-positive thyroid cancer in an animal model will be of interest. Our in vitro experiments documented the effects of WR-1065 on thyroid cancer and fibroblast cells response to the DNA-damaging agents, but did not address specifically the potential effects of WR-1065 on thyroid cancer microenvironment, specifically cancerassociated fibroblasts. Further experiments with the use of animal model of thyroid cancer could provide an important information regarding the effect of WR-1065

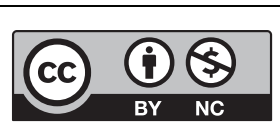

This work is licensed under a Creative Commons Attribution-NonCommercial 4.0 International License. 
on thyroid cancer-associated fibroblasts and on the tumor microenvironment.

In summary, amifostine as a pharmacologic modulator of the biological response to radiation injury may represent an alternative concept in radioprotection for patients with thyroid cancer. Our data show that WR1065 had no protective effect on thyroid cancer cells against DNA-damaging agents in vitro and suggest that amifostine will not attenuate the efficacy of radioiodine treatment in patients with thyroid cancer. Results demonstrating WR-1065 cytotoxicity suggest potential utility of antioxidant agents in the treatment of thyroid cancer and warrant further evaluation.

\section{Declaration of interest}

The authors declare that they have no competing interests. The views presented in this manuscript are those of the authors; no endorsement by the USUHS or Department of Defense has been given or should be inferred.

\section{Funding}

This work did not receive any specific grant from any funding agency in the public, commercial, or not-for-profit sector.

\section{References}

1 Haugen BR, Alexander EK, Bible KC, Doherty GM, Mandel SJ, Nikiforov YE, Pacini F, Randolph GW, Sawka AM, Schlumberger M et al. 2015 American Thyroid Association Management Guidelines for adult patients with thyroid nodules and differentiated thyroid cancer: the American Thyroid Association Guidelines task force on thyroid nodules and differentiated thyroid cancer. Thyroid 201626 1-133. (doi:10.1089/thy.2015.0020)

2 Akulevich NM, Saenko VA, Rogounovitch TI, Drozd VM, Lushnikov EF, Ivanov VK, Mitsutake N, Kominami R \& Yamashita S. Polymorphisms of DNA damage response genes in radiation-related and sporadic papillary thyroid carcinoma. Endocrine-Related Cancer 200916 491-503. (doi:10.1677/ERC-08-0336)

3 Bohuslavizki KH, Klutmann S, Bleckmann C, Brenner W, Lassmann S, Mester J, Henze E \& Clausen M. Salivary gland protection by amifostine in high-dose radioiodine therapy of differentiated thyroid cancer. Strahlentherapie und Onkologie 1999175 57-61. (doi:10.1007/ BF02753843)

4 Mandel SJ \& Mandel L. Radioactive iodine and the salivary glands. Thyroid 200313 265-271. (doi:10.1089/105072503321582060)

5 Provinciali M, Ciavattini A, Di Stefano G, Argentati K \& Garzetti GG et al. In vivo amifostine (WR-2721) prevents chemotherapy-induced apoptosis of peripheral blood lymphocytes from cancer patients. Life Sciences 199964 1525-1532. (doi:10.1016/S0024-3205(99)00096-X)

6 Tannehill SP, Mehta MP, Larson M, Storer B, Pellet J, Kinsella TJ $\&$ Schiller JH. Effect of amifostine on toxicities associated with sequential chemotherapy and radiation therapy for unresectable non-small-cell lung cancer: results of a phase II trial. Journal of Clinical Oncology 199715 2850-2857. (doi:10.1200/JCO.1997.15.8.2850)

7 Grdina DJ, Kataoka Y \& Murley JS. Amifostine: mechanisms of action underlying cytoprotection and chemoprevention. Drug Metabolism and Drug Interactions 200016 237-279. (doi:10.1515/ DMDI.2000.16.4.237)
8 Buntzel J, Schuth J, Kuttner K \& Glatzel M. Radiochemotherapy with amifostine cytoprotection for head and neck cancer. Support Care in Cancer 19986 155-160. (doi:10.1007/s005200050150)

9 Bohuslavizki KH, Klutmann S, Brenner W, Kroger S, Buchert R, Bleckmann C, Mester J, Henze E \& Clausen M. Radioprotection of salivary glands by amifostine in high-dose radioiodine treatment. Results of a double-blinded, placebo-controlled study in patients with differentiated thyroid cancer. Strahlentherapie und Onkologie 1999175 (Supplement 4) 6-12.

10 Ma C, Xie J, Jiang Z, Wang G \& Zuo S. Does amifostine have radioprotective effects on salivary glands in high-dose radioactive iodine-treated differentiated thyroid cancer. European Journal of Nuclear Medicine and Molecular Imaging 201037 1778-1785. (doi:10.1007/s00259-009-1368-6)

11 Korst AE, van der Sterre ML, Gall HE, Fichtinger-Schepman AM, Vermorken JB \& van der Vijgh WJ. Influence of amifostine on the pharmacokinetics of cisplatin in cancer patients. Clinical Cancer Research 19984 331-336.

12 Khodarev NN, Kataoka Y, Murley JS, Weichselbaum RR \& Grdina DJ Interaction of amifostine and ionizing radiation on transcriptional patterns of apoptotic genes expressed in human microvascular endothelial cells (HMEC). International Journal of Radiation Oncology, Biology, Physics 200460 553-563. (doi:10.1016/j.ijrobp.2004.04.060)

13 Liu SC, Murley JS, Woloschak G \& Grdina DJ. Repression of c-myc gene expression by the thiol and disulfide forms of the cytoprotector amifostine. Carcinogenesis 199718 2457-2459. (doi:10.1093/ carcin/18.12.2457)

14 Lee EJ, Gerhold M, Palmer MW \& Christen RD. p53 protein regulates the effects of amifostine on apoptosis, cell cycle progression, and cytoprotection. British Journal of Cancer $2003 \mathbf{8 8} 754-759$. (doi:10.1038/sj.bjc.6600779)

15 Brizel DM, Wasserman TH, Henke M, Strnad V, Rudat V, Monnier A, Eschwege F, Zhang J, Russell L, Oster W et al. Phase III randomized trial of amifostine as a radioprotector in head and neck cancer. Journal of Clinical Oncology 200018 3339-3345. (doi:10.1200/ JCO.2000.18.19.3339)

16 Kemp G, Rose P, Lurain J, Berman M, Manetta A, Roullet B, Homesley H, Belpomme D \& Glick J. Amifostine pretreatment for protection against cyclophosphamide-induced and cisplatininduced toxicities: results of a randomized control trial in patients with advanced ovarian cancer. Journal of Clinical Oncology 199614 2101-2112. (doi:10.1200/JCO.1996.14.7.2101)

17 Choi JS, An HY, Park IS, Kim SK, Kim YM \& Lim JY. Radioprotective effect of epigallocatechin-3-gallate on salivary gland dysfunction after radioiodine ablation in a murine model. Clinical and Experimental Otorhinolaryngology 20169 244-251. (doi:10.21053/ceo.2015.01011)

18 Brizel DM \& Overgaard J. Does amifostine have a role in chemoradiation treatment? Lancet Oncology 20034 378-381. (doi:10.1016/S1470-2045(03)01132-X)

19 Pataer A, Fanale MA, Roth JA, Swisher SG \& Hunt KK. Induction of apoptosis in human lung cancer cells following treatment with amifostine and an adenoviral vector containing wild-type p53. Cancer Gene Therapy 200613 806-814. (doi:10.1038/sj.cgt.7700960)

20 North S, El-Ghissassi F, Pluquet O, Verhaegh G \& Hainaut P. The cytoprotective aminothiol WR1065 activates p21waf-1 and down regulates cell cycle progression through a p53-dependent pathway. Oncogene 200019 1206-1214. (doi:10.1038/sj.onc.1203413)

21 Luo W, Wu F, Elmaoued R, Beck BB, Fischer E, Meng X, Leslie KK \& Dai D. Amifostine enhancement of the anti-cancer effects of paclitaxel in endometrial cancer is TP53-dependent. International Journal of Oncology 201037 1187-1194.

22 Valerie K, Yacoub A, Hagan MP, Curiel DT, Fisher PB, Grant S \& Dent P. Radiation-induced cell signaling: inside-out and outside-in Molecular Cancer Therapeutics 20076 789-801. (doi:10.1158/15357163.MCT-06-0596)

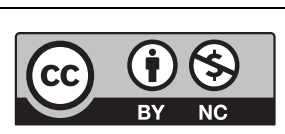

This work is licensed under a Creative Commons Attribution-NonCommercial 4.0 International License. 
23 Ribizzi I, Darnowski JW, Goulette FA, Sertoli MR \& Calabresi P. Amifostine cytotoxicity and induction of apoptosis in a human myelodysplastic cell line. Leukocyte Research 200024 519-525. (doi:10.1016/S0145-2126(00)00007-2)

24 Brenner B, Wasserman L, Beery E, Nordenberg J, Schechter J, Gutman H \& Fenig E. Variable cytotoxicity of amifostine in malignant and non-malignant cell lines. Oncology Reports 200310 $1609-1613$.
25 Dai D, Holmes AM, Nguyen T, Davies S, Theele DP, Verschraegen C \& Leslie KK. A potential synergistic anticancer effect of paclitaxel and amifostine on endometrial cancer. Cancer Research 200565 9517-9524. (doi:10.1158/0008-5472.CAN-05-1613)

26 Glover D, Glick JH, Weiler C, Fox K \& Guerry D. WR-2721 and highdose cisplatin: an active combination in the treatment of metastatic melanoma. Journal of Clinical Oncology 19875 574-578. (doi:10.1200/ JCO.1987.5.4.574)

Received in final form 28 July 2017

Accepted 8 August 2017

Accepted Preprint published online 8 August 2017
This work is licensed under a Creative Commons Attribution-NonCommercial 4.0 International License. 